2. To: (Receiving Organization)
BUILDING 324

5. Proj./Prog./Dept./Div.:

B CELL CLEANOUT PROJECT

8. Originator Remarks:

QAPP for B Cell Cleanout Project.

(Non-Engineering EDT)
3. From: (Originating Organization) BUILDING 324 PROJECTS

6. Design Authority/ Design Agent/Cog. Engr.:

JM TANKE
11. Receiver Remarks:
11A. Design Baseline Document?
[] Yes
$[X]$ No
4. Related EDT No.:
7. Purchase Order No.:

9. Equip./Component No.:

10. System/Bldg./Facility: Building 324

12. Major Assm. Dwg. No.:

13. Permit/Permit Application No.:

14. Required Response Date:

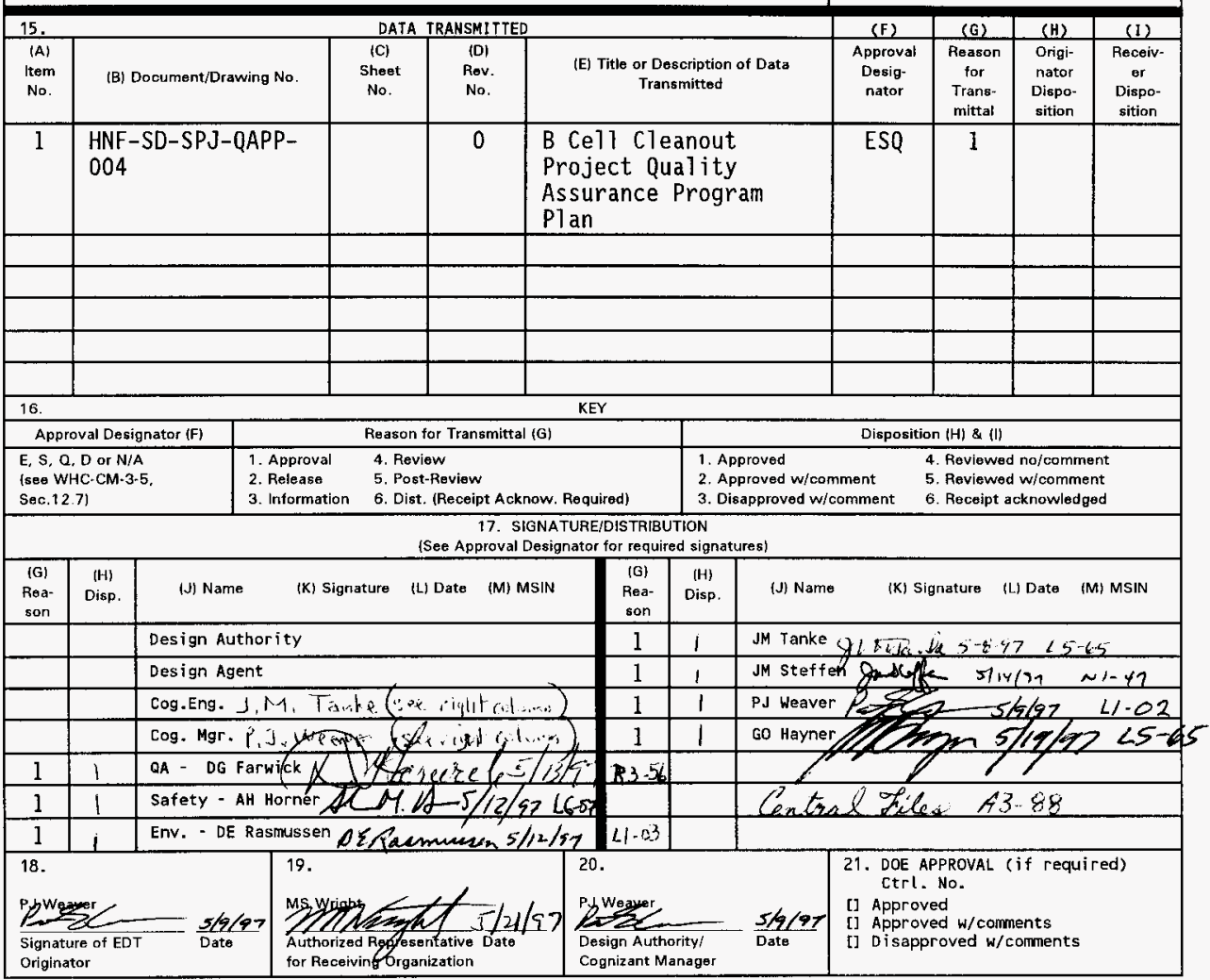

BD-7400-172-2 (05/96) GEF097 


\section{Quality Assurance Program Plan for 324 Building B Cell Safety Cleanout Project (BCCP)}

J. M. Tanke

B\&W Hanford Company, Richland. WA 99352

U.S. Department of Energy Contract DE-AC06-96RL13200

EDT/ECN: 616479

Org Code: 19200

UC: 2050

B\&R Code: EX3120020

Charge Code: K402?

Tota 7 Pages: 14

Key words: QAPP, B Ce11, Cleanout, BCCP

Abstract: This QAPP implements the Quality Assurance Program Plan for the 324 Building B Cell Safety Cleanout Project.

IRADEMARK DISCLAIMER. Reference herein to any specific commercial product, process, or service by trade name, trademark, manufacturer, or otherwise, does not necessarily constitute or imply its endorsement, recomendation, or favoring by the United States Government or any agency thereof or its contractors or subcontractors.

Printed in the United States of America. To obtain copies of this document, contact: Document Control Services, P.0. Box 950, Mailstop H6-08, Richland WA 99352, Phone (509) 372-2420; Fax (509) 376-4989.
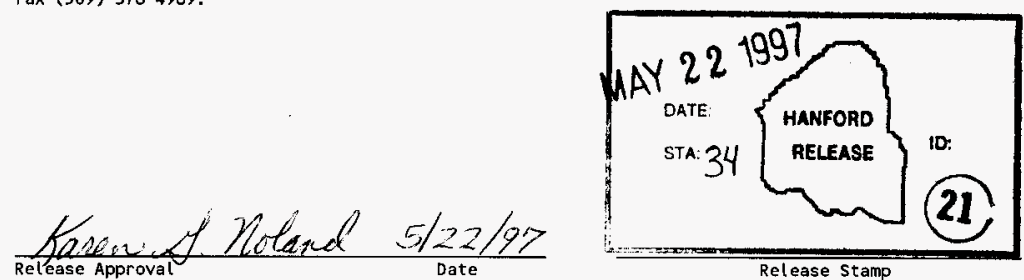

\section{Approved for Public Release}


HNF-SD-SPJ-QAPP-004

Rev. 0

324 BUILDING B-CELL SAFETY CLEANOUT PROJECT

QUALITY ASSURANCE PROGRAM PLAN

TABLE OF CONTENTS

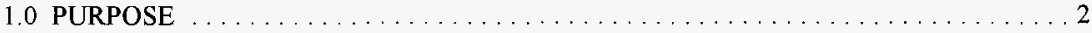

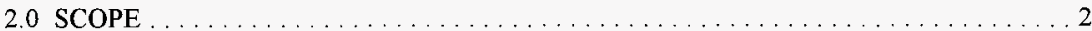

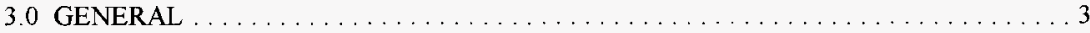

4.0 QUALITY ASSURANCE CRITERIA . . . . . . . . . . . . . . . . . . . . 3

4 MANAGEMENT - Program ....................... 3

4.2 MANAGEMENT - Personnel Training and Qualification $\ldots \ldots \ldots \ldots \ldots$

4.3 MANAGEMENT - Quality Improvement .................... 4

4.4 MANAGEMENT - Documents and Records . . . . . . . . . . . . . . . 5

4.5 PERFORMANCE - Work Processes $\ldots \ldots \ldots \ldots \ldots \ldots \ldots \ldots \ldots \ldots$

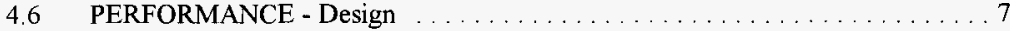

4.7 PERFORMANCE - Procurement ...................... 7

4.8 PERFORMANCE - Inspection and Acceptance Testing . . . . . . . . . 8

4.9 ASSESSMENT - Management Assessment $\ldots \ldots \ldots \ldots \ldots \ldots \ldots$

4.10 ASSESSMENT - Independent Assessment . . . . . . . . . . . . . . 9

LIST OF TABLES

Table 1 Quality Assurance Program Index 
HNF-SD-SPJ-QAPP-004

Rev. 0

\section{BUILDING B-CELL SAFETY CLEANOUT PROJECT QUALITY ASSURANCE PROGRAM PLAN}

\subsection{PURPOSE}

This Quality Assurance Program Plan (QAPP) provides information on how the Quality Assurance Program is implemented for the 324 Building B-Cell Safety Cleanout Project (BCCP). This QAPP is responsive to the Westinghouse Hanford Company Quality Assurance Program and Implementation Plan, WHC-SP-1 131, for 10 CFR 830.120, "Nuclear Safety Management, Quality Assurance Requirements"; and DOE Order 5700.6C, "Quality Assurance". This QAPP supersedes PNNL PNL-MA-70 QAP "Quality Assurance Plan No. WTC-050 Rev. 2", issue date May 3, 1996.

\subsection{SCOPE}

This QAPP has been developed specifically for the BCCP. It applies to those items and tasks which affect the completion of activities identified in the work breakdown structure of the Project Management Plan (PMP). These activities include all aspects of decontaminating B-Cell and project related operations within the 324 Building as it relates to the specific activities of this project. General facility activities (i.e. 324 Building Operations) are covered in the Building 324 QAPP. In addition, this QAPP supports the related quality assurance activities addressed in CM-2-14, Hazardous Material Packaging and Shipping, and HSRCM-1, Hanford Site Radiological Control Manual.

The 324 Building is currently transitioning from being a Pacific Northwest National Laboratory (PNNL) managed facility to a $\mathbf{B} \& W$ Hanford Company (BWHC) managed facility During this transition process existing, PNNL procedures and documents will be utilized until replaced by $\mathrm{BWHC}$ procedures and documents. These documents conform to the requirements found in PNL-MA-70, Quality Assurance Manual and PNL-MA-81, Hazardous Materials Shipping Manual.

The Quality Assurance Program Index (QAPI) contained in Table 1 provides a matrix which shows how project activities relate to 10 CFR 830.120 and $5700.6 \mathrm{C}$ criteria. Quality Assurance program requirements will be addressed separate from the requirements specified in this document. Other Hanford Site organizations/companies may be utilized in support of this project and the subject organizations are to implement applicable Quality Assurance requirements consistent with this QAPP. 


\section{BUILDING B-CELL SAFETY CLEANOUT PROJECT QUALITY ASSURANCE PROGRAM PLAN}

\subsection{GENERAL}

Quality assurance requirements are to be applied to specific items within each of the major activities identified in the work breakdown structure. These specific items have been identified in the "Applicability" section of each requirement

\subsection{QUALITY ASSURANCE CRITERIA}

\subsection{Management - Program}

\subsubsection{Requirement}

A written Quality Assurance Program (QAP) shall be developed, implemented, and maintained. The QAP shall describe the organizational structure, functional responsibilities, levels of authority, and interfaces for those managing, performing, and assessing the work. The QAP shall describe management processes, including planning, scheduling, and resource considerations.

\subsubsection{Implementation}

The site QAP is described in WHC-SP-1131 and is based on 10 CFR 830.120. The QAP provides methods and procedures to verify compliance with quality requirements. This QAPP implements the QAP for work activities affecting completion of the BCCP consistent with the scope of this project. Project-specific procedures are to be used to implement quality requirements when established standards and site procedures do not provide sufficient direction.

The project manager has overall responsibility for compliance with the QA program. Project personnel at all levels are responsible for planning, implementing and assessing programs for design, construction, and operation of systems controlling project activities.

Various site contractors and subcontractors are involved in the activities associated with this project. The PMP identifies the project participants and their responsibilities and interfaces. Additional responsibilities or new activities not described in the PMP are to be defined and detail provided in specific plans and procedures or use the requirements provided herein.

\subsubsection{Applicability}

This QAPP provides overall guidance and quality requirements for the project. The development of other project-specific quality assurance project plans is not required. 


\section{BUILDING B-CELL SAFETY CLEANOUT PROJECT QUALITY ASSURANCE PROGRAM PLAN}

\subsection{MANAGEMENT - Personnel Training and Qualification}

\subsubsection{Requirement}

Personnel shall be trained and qualified to ensure they are capable of performing their assigned work. Personnel shall be provided continuing training to ensure that job proficiency is maintained.

\subsubsection{Implementation}

The training tracking system(s) provide management with a method to ensure that personnel qualifications are current. Personnel performing normal operational tasks (i.e. operating the hot cell equipment) are required to meet the training requirements usually associated with that work. Records documenting this training are to be maintained and be available for review by project management.

Organizations performing special project-specific tasks/processes are to define and/or provide personnel training and qualification in these processes. These personnel are to be qualified prior to performing these tasks. Records documenting the training are to be maintained by personnel designated in the applicable qualification procedures.

\subsubsection{Applicability}

Personnel are to be trained and qualified for the following tasks.

Operation of size reduction equipment

Operation of decontamination equipment

Loading material into containers

Loading containers into casks

\subsection{MANAGEMENT - Quality Improvement}

\subsubsection{Requirement}

Processes to detect and prevent quality problems shall be established and implemented. Items, services, and processes that do not meet established requirements shall be identified, controlled, and corrected according to the importance of the problem and the work affected. Correction shall include identifying the causes of problems and working to prevent recurrence. Item characteristics, process implementation, and other quality-related information shall be reviewed and the data analyzed to identify items, services, and processes needing improvement. 


\section{HNF-SD-SPJ-QAPP-004}

Rev. 0

\section{BUILDING B-CELL SAFETY CLEANOUT PROJECT QUALITY ASSURANCE PROGRAM PLAN}

\subsubsection{Implementation}

Direct observation and review of ongoing work, tests, completed work, or modifications is to be conducted to detect and prevent errors and problems. Nonconformance, Surveillance and Occurrence Reports are also to be used to reveal conditions adverse to project quality requirements. Procedures are to provide a systematic means for obtaining commitments for corrective action from responsible management and for follow-up to verify the completion and effectiveness of the action. When adverse conditions are identified emphasis is to be placed on implementation of corrective action to prevent recurrence, not just remedial action which only corrects the specific deficiency.

\subsubsection{Applicability}

Existing nonconformance and corrective action management systems are to be used. Nonconformance reports and corrective actions willbe tracked on the Hanford Action Tracking System (HATS). The development of new project-specific system is not required.

\subsection{MANAGEMENT - Documents and Records}

\subsubsection{Requirement}

Documents shall be prepared, reviewed, approved, issued, used, and revised to prescribe processes, specify requirements, or establish design. Records shall be specified, prepared, reviewed, approved, and maintained.

\subsubsection{Implementation}

All documents that are used to perform administrative, design, construction, inspection, testing, operating, and maintenance activities are to be prepared, issued, and changed in accordance with approved procedures.

Records that are used to document the performance of administrative, design, construction, inspection, testing, operating, and maintenance activities are to be prepared, reviewed, approved and changed in accordance with approved procedures.

Existing document and records management systems are to be used. The development of a new project-specific system is not required. 
HNF-SD-SPJ-QAPP-004

Rev. 0

\section{BUILDING B-CELL SAFETY CLEANOUT PROJECT QUALITY ASSURANCE PROGRAM PLAN}

\subsubsection{Applicability}

Document and records control is required, as appropriate, for the following anticipated activities.

Surveillance reports

Inspection and testing reports

Shipping, handling and storage documentation/procedures

Work \& test plan(s)/procedures

\subsection{PERFORMANCE - Work Processes}

\subsubsection{Requirement}

Work shall be performed to established technical standards and administrative controls using approved instructions, procedures, or other appropriate means. Items shall be identified and controlled to ensure their proper use. Items shall be maintained to prevent their damage, loss, or deterioration. Equipment used for process monitoring or data collection shall be calibrated and maintained.

\subsubsection{Implementation}

Policies and procedures are to be established to ensure that the quality of the work being performed is in compliance with applicable standards, regulations, and codes. The level of detail of work instructions is to be consistent with the items' complexity and the consequence of failure.

Packaging, handling, shipping, and storage of materials and equipment is to be done by qualified project and support personnel. Items are to be controlled to prevent damage or loss and to provide adequate safety of personnel involved.

Existing work control systems are to be used. The development of new project-specific work control systems are not required, however, project-specific work documents are to be developed and utilized as necessary.

\subsubsection{Applicability}

Work process controls are required, as appropriate, for the following activities.

Operational testing of hot cell equipment

Loading material into containers

Transport of containers 


\subsection{PERFORMANCE - Design}

\subsubsection{Requirement}

Items and processes shall be designed using sound engineering/scientific principles and appropriate standards. Design work, including changes, shall incorporate applicable requirements and design bases. Design interfaces shall be identified and controlled. The adequacy of design products shall be verified or validated by individuals or groups other than those who performed the work. Verification and validation work shall be completed before approval and implementation of the design.

\subsubsection{Implementation}

Design control requirements for the project are implemented through site manuals and procedures. No project-specific documents/procedures are required. Qualified project and support personnel are to initiate and support design activities in accordance with site manuals and procedures.

\subsubsection{Applicability}

Design control is required, as a minimum, for the following activities.

Container design

Design of special equipment/processes

\subsection{PERFORMANCE - Procurement}

\subsubsection{Requirement}

Procured items and services shall meet established requirements and perform as specified. Prospective suppliers shall be evaluated and selected on the basis of specified criteria. Processes to ensure that approved suppliers continue to provide acceptable items and services shall be established and implemented.

\subsubsection{Implementation}

Procurement requirements are implemented through site manuals and procedures. Projectspecific documents/procedures apply to control of material after receipt on site. Personnel assigned to support the project are to initiate and support procurement activities in accordance with site manuals. 
Rev. 0

\section{BUILDING B-CELL SAFETY CLEANOUT PROJECT QUALITY ASSURANCE PROGRAM PLAN}

Procurement requisitions are to be reviewed to assure that appropriate quality assurance requirements and procurement clauses are specified. These clauses include control of purchased items, supplier performance, evaluation, acceptance of the item or service, supplier audits, and records confirming that specified requirements are obtained.

\subsubsection{Applicability}

Procurement control is required, as appropriate, for the following activities.

No special procurement is anticipated

\subsection{PERFORMANCE - Inspection and Acceptance Testing}

\subsubsection{Requirement}

Inspection and testing of specified items, services, and processes shall be conducted using established acceptance and performance criteria. Equipment used for inspections and tests shall be calibrated and maintained.

\subsubsection{Implementation}

Inspections of ongoing work, completed work, or modifications are to be conducted by qualified/certified project and support personnel. Inspection for acceptance is to be performed by qualified inspection personnel. Inspections are to be performed in accordance with inspection criteria included in work plans and related documents.

\subsubsection{Applicability}

Inspection and acceptance testing is required, as appropriate, for the following activities.

Inspection of containers

Transportation activities

Inspection of containers prior to transport 
Rev. 0

\section{BUILDING B-CELL SAFETY CLEANOUT PROJECT QUALITY ASSURANCE PROGRAM PLAN}

\subsection{ASSESSMENT - Management Assessment}

\subsubsection{Requirement}

Managers shall assess their management processes. Problems that hinder the organization from achieving its objectives shall be identified and corrected.

\subsubsection{Implementation}

Project Management is to regularly assess the adequacy of management systems and processes to ensure effective implementation. These assessments are to include the participation of project management and project team personnel. Team members are to take responsibility for their work and critically assess their efforts to determine if they have met their task objectives. Management is to identify problems and barriers that hinder the project from achieving project objectives. Project Management is to determine what response actions are appropriate, and implement corrective actions based on the impact of the assessment results on safety and project deliverables.

\subsubsection{Applicability}

Due to the transition from PNNL to BWHC procedures management assessments will be scheduled. Senior management will determine the scope of the assessments for the project. In addition, assessment of activities will be a part of project status meetings and carried out as a part of inspection and testing.

\subsection{ASSESSMENT - Independent Assessment}

\subsubsection{Requirement}

Independent assessments shall be planned and conducted to measure item and service quality, to measure the adequacy of work performance, and to promote improvement. The group performing independent assessments shall have sufficient authority and freedom from the line to carry out its responsibilities. Persons conducting independent assessments shall be technically qualified and knowledgeable in the areas assessed.

\subsubsection{Implementation}

Planned and scheduled independent assessments are to be performance based and performed to measure item and service quality, the adequacy of work performance, compliance 
HNF-SD-SPJ-QAPP-004

Rev. 0

\section{BUILDING B-CELL SAFETY CLEANOUT PROJECT} QUALITY ASSURANCE PROGRAM PLAN

with all aspects of the Quality Assurance Program and to determine its effectiveness, and to promote improvement.

\subsubsection{Applicability}

Due to the short duration of this project it is not anticipated that any formal independent assessments will be scheduled or performed on the project. An independent assessment of the Facility is scheduled for October 1997 and will provide overall assessment of operations that include the B-Cell Cleanout Project. 
HNF-SD-SPJ-QAPP-004

Rev. 0

324 BUILDING B-CELL SAFETY CLEANOUT PROJECT

QUALITY ASSURANCE PROGRAM PLAN

Table 1 Quality Assurance Program Index

(Page 1 of 3)

\begin{tabular}{|c|c|c|c|}
\hline \multirow{2}{*}{$\begin{array}{l}\text { 10CFR 830.120/ } \\
\text { SP-1131 } \\
\text { QA CRITERIA } \\
\text { SECTIONS }\end{array}$} & \multicolumn{2}{|c|}{$\begin{array}{c}\text { SITE WIDE } \\
\text { (HNF Manuals) }\end{array}$} & \multirow{2}{*}{$\begin{array}{l}\text { B-CELL CLEANOUT } \\
\text { PROJECT }\end{array}$} \\
\hline & $\begin{array}{c}\text { QA POLICY AND } \\
\text { IMPLEMENTING } \\
\text { DOCUMENTS } \\
\text { CM-4-2 } \\
\end{array}$ & $\begin{array}{c}\text { Others } \\
\text { (Used when applicable) }\end{array}$ & \\
\hline \multicolumn{4}{|l|}{ (1) MANAGEMENT } \\
\hline $\begin{array}{l}\text { (1)(I) } \\
\text { Program }\end{array}$ & $\begin{array}{l}\mathrm{QR} \text { I.0, QR } 2.0 \\
\mathrm{Q} \text { I 2. I, Q1 } 2.2\end{array}$ & $\begin{array}{c}\text { CM-1, CM-1-3 } \\
\text { CM-1-5, CM-2-14 } \\
\text { CM-3-5, CM-4-46 CM-6-1, } \\
\text { CM-6-2 CM-7-5, EP-0063 }\end{array}$ & $\begin{array}{c}\text { Building } 324 \text { QAPP, } 4.1 .3 \text { of } \\
\text { this QAPP }\end{array}$ \\
\hline $\begin{array}{l}\qquad \text { (1)(ii) } \\
\text { Personnel Training } \\
\text { and Qualification }\end{array}$ & $\begin{array}{l}\text { QR 2.0, QI } 2.6 \\
\text { QR 9.0, QR } 10.0\end{array}$ & $\begin{array}{c}\text { CM-2-14, CM-2-15 } \\
\text { CM-4-5, CM-4-39 CM-7-5, } \\
\text { EP-0063 } \\
\text { IP-1184 }\end{array}$ & $\begin{array}{c}\text { Building } 324 \text { QAPP, } 4.2 .3 \text { of } \\
\text { this QAPP }\end{array}$ \\
\hline $\begin{array}{l}\text { (1)(iii) } \\
\text { Quality Improvement }\end{array}$ & $\begin{array}{l}\text { QR } 15.0, \text { QI } 15.1 \\
\text { QI } 15.2, \text { QI } 15.6 \\
\text { QR } 16.0, \text { QI } 16.1\end{array}$ & $\begin{array}{l}\text { CM-1-3, CM-1-4 } \\
\text { CM-1-5, CM-6-1 } \\
\text { CM-6-2, CM-7-5 }\end{array}$ & $\begin{array}{c}\text { Building } 324 \text { QAPP, } 4.3 .3 \text { of } \\
\text { this QAPP }\end{array}$ \\
\hline $\begin{array}{l}\text { (1)(iv) } \\
\text { Documents } \\
\text { and Records }\end{array}$ & $\begin{array}{c}\text { QR 6.0, QR 17.0 } \\
\text { QI 17.1, QI } 17.2 \\
\text { QR } 19.0\end{array}$ & $\begin{array}{c}\text { CM-1-3, CM-2-14 } \\
\text { CM-2-15, CM-3-4 CM-3-5, } \\
\text { CM-3-8 CM-3-10, CM-4-5 } \\
\text { CM-6-1, CM-6-2 CM-7-5, } \\
\text { CM-8-7 } \\
\text { EP-0063 }\end{array}$ & $\begin{array}{c}\text { Building } 324 \text { QAPP, } 4.4 .3 \text { of } \\
\text { this QAPP }\end{array}$ \\
\hline
\end{tabular}


Rev. 0

\section{BUILDING B-CELL SAFETY CLEANOUT PROJECT \\ QUALITY ASSURANCE PROGRAM PLAN}

Table 1. Quality Assurance Program Index

(Page 2 of 3)

\begin{tabular}{|c|c|c|c|}
\hline \multirow{2}{*}{$\begin{array}{l}\text { 10CFR } 830.120 / \\
\text { WHC-SP-1131 } \\
\text { QA CRITERIA } \\
\text { SECTIONS }\end{array}$} & \multicolumn{2}{|c|}{ SITE WIDE } & \multirow{2}{*}{$\begin{array}{l}\text { B-CELL CLEANOUT } \\
\text { PROJECT }\end{array}$} \\
\hline & $\begin{array}{c}\text { QA POLICY \& } \\
\text { IMPLEMENTATION } \\
\text { DOCUMENTS } \\
\text { CM-4-2 }\end{array}$ & $\begin{array}{c}\text { Others } \\
\text { (Used when applicable) }\end{array}$ & \\
\hline \multicolumn{4}{|l|}{$\begin{array}{c}\text { (2) } \\
\text { PERFORMANCE }\end{array}$} \\
\hline $\begin{array}{l}\qquad(2)(1) \\
\text { Work Processes }\end{array}$ & $\begin{array}{c}\text { QR 5.0, QR 8.0 } \\
\text { QR 9.0, QI 9.1 } \\
\text { QI 9.2, QR 11.0 } \\
\text { QR 12.0, QI } 12.2 \\
\text { QI 12.3, QI } 12.4 \\
\text { QI 12.5, QI } 12.6 \\
\text { QI 12.7, QR } 13.0 \\
\text { QI } 13.3, \text { QI } 13.4 \\
\text { QR } 14.0, \text { QI } 14.1 \\
\text { QR } 19.0\end{array}$ & $\begin{array}{c}\text { CM-1-3, CM-1-5 } \\
\text { CM-1-8, CM-1-10 CM-2- } \\
\text { 1, CM-2-2 CM-2-3, CM- } \\
2-4 \text { CM-2-14, CM-3-5 } \\
\text { CM-4-5, CM-4-38 CM-4- } \\
39, \\
\text { CM-4-41, CM-5-4 } \\
\text { CM-5-16, CM-6-1 } \\
\text { CM-6-2, CM-6-10 } \\
\text { CM-7-7, CM-8-7 } \\
\text { DOE-RL-92-36 } \\
\text { HSRCM-1 }\end{array}$ & $\begin{array}{c}\text { Building } 324 \text { QAPP, } 4.5 .3 \\
\text { of this QAPP }\end{array}$ \\
\hline $\begin{array}{l}\text { (2)(ii) } \\
\text { Design }\end{array}$ & $\begin{array}{c}\text { QR 3.0, QR } 5.0 \\
\text { QR } 19.0\end{array}$ & $\begin{array}{c}\text { CM-1-3, CM-1-8 } \\
\text { CM-2-14, CM-3-5 } \\
\text { CM-3-10, CM-4-5 CM-4- } \\
46, \text { CM-6-1 CM-6-2, EP- } \\
0063\end{array}$ & $\begin{array}{c}\text { Building } 324 \text { QAPP, } 4.6 .3 \\
\text { of this QAPP }\end{array}$ \\
\hline $\begin{array}{l}\text { (2)(iii) } \\
\text { Procurement }\end{array}$ & $\begin{array}{l}\text { QR 4.0, QI 4.1 } \\
\text { QR 7.0, QI 7.1 } \\
\text { QI 7.2, QI 7.3 } \\
\text { QI 7.6, QR 15.0, } \\
\text { QR } 15.6\end{array}$ & $\begin{array}{l}\text { CM-1-3, CM-2-1 } \\
\text { CM-2-2, CM-2-3 } \\
\text { CM-3-5, CM-4-5 } \\
\text { CM-6-1, CM-6-2 }\end{array}$ & $\begin{array}{c}\text { Building } 324 \text { QAPP, } 4.7 .3 \\
\text { of this QAPP }\end{array}$ \\
\hline $\begin{array}{c}\text { 9(2)(iv) } \\
\text { Inspection and } \\
\text { Acceptance Testing }\end{array}$ & $\begin{array}{c}\mathrm{QI} 7.4, \mathrm{QR} 10.0, \mathrm{QI} 10.2 \\
\mathrm{QR} 11.0, \mathrm{QR} 12.0 \mathrm{QI} \\
12.2, \mathrm{QI} 12.3 \mathrm{QI} 12.4, \mathrm{QI} \\
12.5 \mathrm{QI} 12.6, \mathrm{QI} 12.7 \mathrm{QR} \\
14.0, \mathrm{QR} 19.0\end{array}$ & $\begin{array}{c}\text { CM-1-3, CM-1-4 } \\
\text { CM-1-8, CM-2-14 } \\
\text { CM-3-5, CM-4-5 CM-4- } \\
41, \text { CM-5-4 CM-6-1, CM- } \\
6-2 \\
\text { EP-0063 }\end{array}$ & $\begin{array}{c}\text { Building } 324 \text { QAPP, } 4.8 .3 \\
\text { of this QAPP }\end{array}$ \\
\hline
\end{tabular}


HNF-SD-SPJ-QAPP-004

Rev. 0

324 BULLDING B-CELL SAFETY CLEANOUT PROJECT QUALITY ASSURANCE PROGRAM PLAN

\begin{tabular}{|c|c|c|c|}
\hline \multirow{2}{*}{$\begin{array}{l}\text { 10CFR 830.120/ } \\
\text { WHC-SP-1131 } \\
\text { QA CRITERIA } \\
\text { SECTIONS }\end{array}$} & \multicolumn{2}{|c|}{ SITE WIDE } & \multirow{2}{*}{$\begin{array}{l}\text { B-CELL CLEANOUT } \\
\text { PROJECT }\end{array}$} \\
\hline & $\begin{array}{c}\text { QA POLICY \& } \\
\text { IMPLEMENTATION } \\
\text { DOCUMENTS } \\
\text { CM-4-2 } \\
\end{array}$ & $\begin{array}{c}\text { Others } \\
\text { (Used when applicable) }\end{array}$ & \\
\hline \multicolumn{4}{|l|}{ (3) ASSESSMENT } \\
\hline $\begin{array}{c}\text { (3)(I) } \\
\text { Management } \\
\text { Assessment }\end{array}$ & QR 16.0, QI 16.1 & $\begin{array}{c}\text { CM-1-3, CM-1-4 } \\
\text { CM-1-5, CM-4-5 } \\
\text { CM-7-5 }\end{array}$ & $\begin{array}{c}\text { Building } 324 \text { QAPP, } 4.9 .3 \\
\text { of this QAPP }\end{array}$ \\
\hline $\begin{array}{l}\text { (3)(ii) } \\
\text { Independent } \\
\text { Assessment }\end{array}$ & QR 18.0, QI 18.1 & $\begin{array}{c}\text { CM-1-3, CM-1-4 } \\
\text { CM-4-5, CM-4-6 } \\
\text { CM-6-1, CM-6-2 } \\
\text { CM-7-5 }\end{array}$ & $\begin{array}{c}\text { Building } 324 \text { QAPP, } 4.10 .3 \\
\text { of this QAPP }\end{array}$ \\
\hline
\end{tabular}

